\title{
Linking Digital India As A Tool For Curbing Farmer Suicides - A Case Study Of Telangana State
}

\author{
Dr. Suresh Chandra.Ch, \\ Dr. S. Radhakrishnan Post Doctoral Research Fellow, \\ Department of Commerce \& Business Management, \\ University College of Commerce \& Business Management, \\ Kakatiya University, \\ Warangal, Telangana State-506001 INDIA.
}

(c) Scholedge International Journal of Management \& Development (2394-3378), Vol.03, Issue 03 (2016) pg 74-88. Published by: Scholedge R\&D Center [http://journals.thescholedge.org/] [Email: sijmd@scholedge.org]

\begin{abstract}
Digital India, a prestigious programme of NDA led Government with a projected value of Rs.113000 Crore is aimed to transform India to Digital empowered society and knowledge economy and among the 9 concentrated areas of Digital India, the present study evaluates the Digital India programme as a tool of opportunistic and social welfare initiative to curb one of the most rising problems in the agricultural sector in the country. Though agriculture, still the major employment provider has been in the situation of crisis due to rising farmer suicides. Farmers have been facing problems including lack of agricultural infrastructural assistance from government, lack of financial assistance regularity from banks and most importantly, the sector has been facing the problem of providing marketable information of yield for farmers. All these resulted in depressed conditions to farmers both financially and mentally which have lead to rising suicide cases especially in the last five years. The state of Telangana has been taken as a case for the present study and the study focuses on how Digital India programme can act as a tool of information provider for farmers, remedial practices through Digital India programme for curbing the farmer suicides. The study further deals with the factors influencing Digital India programme and the areas in farming which require Digital India assistance. The study is based on both primary and secondary data sources. Primary data is collected from farmer families in select districts of Telangana State. Secondary data sources include the reports issued by the state government on farmer suicides, agricultural yield, reports from banks and other published sources from internet and news papers.
\end{abstract}

Key words: Confidence model, e-kranti , Empowerment, Geo-informatics ICT, Suicides, Digital India, e-governance.

\section{1) Overview Of Agricultural Scenario In India}

India is a global agricultural powerhouse. It is the world's largest producer of milk, pulses, and spices, and has the world's largest cattle herd (buffaloes), as well as the largest area under wheat, rice and cotton. It is the second largest producer of rice, wheat, cotton, sugarcane, farmed fish, sheep \& goat meat, fruit, vegetables and tea. The country has some $195 \mathrm{~m}$ ha under cultivation of which some 63 percent are rain fed (roughly $125 \mathrm{~m}$ ha) while 37 percent are irrigated (70m ha). Farming in India was seemed as one of the most peculiar task for the cultivators due to its complex nature of work and very less returns of laborious efforts. As per the report of World Bank, it is been observed that nearly 3 quarters of India's families depend on rural incomes. The majority of India's poor (some770 million people or about 70 percent) are found in rural areas. According to the National Sample Survey Office's new survey of India's agricultural households, the average farm household makes Rs.6426 per month.

While agriculture's share in India's economy has progressively declined to less than $15 \%$ due to the high growth rates of the industrial and services sectors, the sector's importance in India's economic and social fabric goes well beyond this indicator. First, 
nearly three-quarters of India's families depend on rural incomes. Second, the majority of India's poor (some 770 million people or about 70 percent) are found in rural areas. And third, India's food security depends on producing cereal crops, as well as increasing its production of fruits, vegetables and milk to meet the demands of a growing population with rising incomes.

Further, the statistics have shown that the value of the harvested crop for a household that predominantly grows that crop, over a six-month agricultural season. Sugarcane is by far the most profitable crop to grow, while paddy (or wheat in the first half of the year) brings a household around Rs 30,000 for a six month season. Further, it is being published that input costs work out to nearly 30 percent of the total output an average farm household gets from a crop. On an average 2.47 acres ( 1 hectare) is the feasible land required to meet the expenses to reach equilibrium. Since, agriculture is considered as one of the major exporters, still it is been employed $50 \%$ of the total work force. It is been recognized one among the very few sectors in India which is considered as demographically the broadest economic sector and plays a significant role in the overall socio-economic fabric of India. Lack of systematic institutional and organizational planning in cultivation, irrigation, harvesting and Institutional finances is not adequately available and minimum purchase price fixed by the government do not reach the poorest farmer. Further, majority of the farmers in India own as little as two acres of land. Cultivation on such small area is not economically feasible. Such small farmers have become vulnerable. Exploitation by the middlemen is the reason put forth for not getting the best price for the produce of the agriculturists.

With regard to the efforts of Government, agricultural debt waiver and debt relief scheme in 2008 to benefit over 36 million farmers. Direct agricultural loan to stressed farmers under so called Kisan credit Card were also covered under this scheme. However, most of the subsidies and welfare schemes announced by the Central and State governments do not reach the poor farmers. On the contrary, only big land lords are benefited by those schemes. The root cause of farmers taking their lives is the increase in their indebtedness and debt burden. Exorbitant interest rates have to be declared illegal and the government has to take strict measures against greedy money lenders. Easy access to institutional credits has to reach the small and marginal farmers, without cumbersome procedures.

\section{2) Digital India - An Overview}

According to Pradip Ninan Thomas (2012), Digital India is a critical attempt both into the theory and practice of the digital in social change. The development of telecommunications, software, mobile telephony, e-governance, ICT, software patenting, offers an entry point into an understanding of the contested nature of the Digital in India via an analysis of theory and practice. As emphasized by Ghosh D K(2006), the synergetic effort of Telecommunication, technology and information technology in the area of economic, social and cultural requirements have given life to the development of Digital India. From the studies of Vikash Daga and Vivek Pandit(2013), it is observed that India will be one of the fastest-growing and most vibrant digital markets in the world. The rise and expansion of digital technologies will challenge economic, political and social orthodoxies at an unsettling pace. Further the authors have felt that Digital India is the cusp of major change for three mutually reinforcing reasons which include billions being invested into technologies like $3 \mathrm{G} / 4 \mathrm{G}$, including government's national broadband plan to expand digital access to 160 million more users and the evolution of low-cost smart devices and India's well-established local content and service eco-system and a strong desire to replace decrepit and restrictive structures in favour of political accountability and enhanced social mobiling.

According to Adrian Athique given the technological and scientific ambitions of India's postcolonial elite, there was an early recognition fo the importance of electronics 
and the necessity of acquiring computer technologies and interpreting this technology for the development of nation both economically fit and dominating in all areas. In the words of Narendra Modi, the present Prime Minister of India(2015), Digital India will be a big step toward changing existing ways the government has been working. It will eliminate unnecessary waste, increase output, and empower citizens. Digital India is expected to ensure government services are made available to citizens of India electronically by reducing paper work. The initiative also plans to connect rural areas with high-speed Internet connectivity and it is expected to complete by 2019. In order to transform the entire ecosystem of public services through the use of information technology, the Government of India has launched the Digital India programme with the vision to transform India into a digitally empowered society and knowledge economy.

As specified in the road map of Digital India, the programme is centered on three key vision areas which include Digital infrastructure as a core utility to every citizen, governance and services on demand and digital Empowerment of citizens. This can be achieved in three stages. In the first stage, the government ensures the availability of high speed internet, utility for delivery of services to citizens by ensuring digital identity, encouraging the citizens in participation in digital and financial space, easy access to a Common Service Centre, Shareable private space on a public cloud and Safe and secure cyber-space.

In the second stage, Seamlessly integrated services across departments or jurisdictions available in real time, entitlement of easy ways of doing business, making financial transactions electronic \& cashless and Leveraging Geospatial Information Systems (GIS) for decision support systems \& development. And in the last stage, the programme is aimed to achieve Universal digital literacy, digital resources in different languages applicable for the nation, Collaborative digital platforms for participative governance by eliminating physical interaction by the citizens for services from Government over documents/certificates.

In order to conduct Digital India programme, the government has made a functional plot form where Ministries / Departments / States would fully leverage the Common and Support ICT Infrastructure would evolve/ lay down standards and policy guidelines, provide technical and handholding support, undertake capacity building, R\&D, Process Reengineering, use of integrated \& interoperable systems and deployment of emerging technologies like cloud \& mobile would be undertaken to enhance the delivery of Government services to citizens. States would be given flexibility to identify for inclusion additional state-specific projects, which are relevant for their socio-economic needs. Public Private Partnerships would be preferred wherever feasible to implement eGovernance projects with adequate management and strategic control.

Adoption of Unique ID would be promoted to facilitate identification, authentication and delivery of benefits. For effective management of the Digital India programme, the programme management structure would consists of a Monitoring Committee on Digital India headed by the Prime Minister, a Digital India Advisory Group chaired by the Minister of Communications and IT and Apex committee chaired by the Cabinet Secretary. Overall, Digital India is an umbrella programme that covers multiple government ministries and departments to achieve 9 broad facilities which include Broad band Highways to all parts of the nation, universal access to mobile connectivity, public internet access programme, e-Governance, eKranti(electronic delivery of services), information for all, electronics manufacturing IT for jobs and more importantly Harvest programmes. The digital India programme aims at pulling together many existing schemes under one roof to facilitative collaborative and participative governance. 


\section{3) Problem Of The Study}

Farming in India has steadily declined due to excessive burden of production, lack of facilities, unskilled farmer's inability to use the information sources and more importantly lack of support. In view of the problems that farmers have been facing right from production to marketing of agricultural produce, the technology driven Digital India programme is observed as a source that can be integrated to farming where the farmers can benefit the advantages of technology in many ways. Digital India is expected to contribute wider assistance if it get planned according to the requirements of the farmers. Increasing farming problems have been demotivating the farmers to either migrate from farming and also sometimes it even resulting in worst scenario where the farmers' suicides keep increasing. In view of this emerging scenario, the present paper is an exploratory attempt to thoroughly examine the problems faced by the farmers in select locations at Telangana state, analyzing the root causes for suicides and an attempt is made to present the integration of Digital India as a tool for providing a model that can assist the farmers there by curbing the suicides in the state.

\section{4) Objectives Of The Study}

The present study focuses on the following objectives.

1. To study the scenario of farming in the state of Telangana and the problems faced by the farmers.

2. To analyze the factors influencing the increase in farmer suicide cases in the state of Telangana.

3. To present the prospective model for Farmers with the integration of Digital India for curbing Farmer suicides.

The study further provides the findings and suggestions on the basis of results.

\section{5) Methodology}

The study is based on analyzing about the Digital India Programme as a tool for curbing farmer suicides. In order to emphasize on this area, the required data is collected from primary data sources which include the preliminary observation on farmer suicide incidents, unstructured discussions with farmer families and the secondary data is collected from the news papers, reports issued by Government of Telangana, Sample survey organizations. For the collection of responses from select farmer families, convenience sampling is applied. The data generated reflects the statistics pertaining to select districts of Telangana State.

\section{6) Analysis}

The detailed analysis on the basis of objectives framed is discussed below.

\section{A) Farming Sector In The State Of Telangana}

The state of Telangana has been officially formed on $2^{\text {nd }}$ June, 2014 which constitute a geographical area of $114840 \mathrm{sq} \mathrm{km}$ with 10 administrative districts and 3.5 crore population having $66 \%$ of the literacy rate. The state is surrounded with 37 revenue divisions. As of May, 2014, the state has the agricultural Land-crop land of $58937.4 \mathrm{sqkm}$. With regard to ground water status, out of 352 mandals, 14 mandals are in critical and 38 mandals are in over exploited condition, 44 have recorded as semi critical. Sustainable growth in Agriculture continues to be core agenda for both the Central and State Governments. Agriculture sector is mainly rainfed and depends to a significant extent on the depleting ground water. As nearly 55.49 percent of the State's population is dependent on some form of farm activity for livelihoods, it is imperative to increase the farm incomes and ensuring sustainable growth in Telangana to reduce poverty. The State of Telangana is semi-arid. The average annual rainfall in the state is about $906 \mathrm{~mm}, 80$ 
percent of which is received from the south-west monsoon (June-September). The rainfall in the State is erratic and uncertain and distribution of the rain fall is uneven in various mandals, thus, making agriculture a proverbial gamble in monsoon. Of the rainfall received during the period from 2004-05 to 2013-14, the annual actual rainfall was lowest in 2004-05 with $614 \mathrm{~mm}$, where as it was the highest in 2013-14 with $1212 \mathrm{~mm}$ as against normal rainfall of $906 \mathrm{~mm}$ in the state. The cropping intensity (the ratio of gross cropped area to net cropped area) is one of the indicators for assessing efficiency of agriculture sector. The cropping intensity for the year 2013-14 increased to 1.27 from 1.22 in 2012-13. The cropping intensity is highest in Nizamabad District (1.67) and lowest in Adilabad district (1.09).

Agriculture plays a pivotal role in the economy of Telangana and the better performance of this sector is vital for inclusive growth. Telangana went in for the Green Revolution in rice cultivation in the 1970s. There have been significant changes in the structure and performance of the agrarian economy in the state in the recent years.

While there is lot of potential for growth in agriculture, there are constraints hampering the same. The major constraints are the low and erratic rainfall leaves many areas under unprecedented drought, while some areas are subjected to floods. Semi-arid climate restricts the growth of natural vegetation, due to which, scope of organic matter development in soils is limited and, therefore, the most soils are inherently poor in available Nitrogen, the chief nutrient for plant growth $63 \%$ of the agriculture is rainfed, which is exposed to the hostilities of climate. Schemes like Rashtriya Krishi Vikas Yojana(RKVY), Agricultural and Farm Mechanization- Nationa Food Security Mission(NFSM), Crop Loan Waiver Scheme 2014-15 have not been that much successful as only $65 \%$ of the farmers was disbursed under Agricultural credit and 34 lakh farmers only got benefited by the Crop Loan Waiver Scheme,2014-15. Overall 8 schemes are under operation in the state to provide the assistance to farmers. Among the farming community, about $85 \%$ of farmers are either marginal or small with poor socioeconomic condition High labour cost and low mechanization levels have increased the cost of cultivation. Agricultural extension is devoid of enough strength and mobility to address each and every farmer at right time.

\section{B) Factors Influencing Farmer Suicides In Telangana State}

As per the statistics released by National Crime Records Bureau of India (NCRB), in the year 2014, Telangana State has recorded 898 farmer suicide cases in comparison with 2568 cases in Maharashtra and 5650 cases in the country. Telangana State has recorded $2^{\text {nd }}$ position in terms of suicides, and the report shown that $23.2 \%$ of the farmers have committed suicide due to excess debts, economic crisis; where as $16.8 \%$ of the farmers have committed suicide due to family problems. Further, the share of suicides has shown extremely high for the age group of 30-60 years. Statistics further revealed that Land holding status of farmers who committed suicide revealed that $44.5 \%$ and $27.9 \%$ of victims were small farmers and marginal farmers respectively, they together accounted for $72.4 \%$ (4,095 out of 5,650$)$ total farmer suicides.

With reference to the case of Telangana State, it is observed that, majority of the farmers in Telangana State have cultivated Cotton for the period 2013-14 and 2014-15. Due to lack of expected rain fall for the period 2013-14, 2014-15, the expected returns for acres has rapidly decreased. The mounting debts, lack of rain fall, lack of growth in the yield has resulted in heavy losses to the farmers. Further, the farmers have been under pressure for marketing the cotton. Annexure 2 shows the detailed list of increase in the cultivation of cotton over the last 10 years. Further, lack of information sources for farmers, resulted in returns for the crop sold at the market. Lack of information on wetness in cotton has also made them to get less returns for the crop in comparison with the Government approved price for cotton (information specified in Annexure 3. 
Annexure 1 shows the detailed sample respondent cases observed during the field survey and from secondary data sources.

For the present study, the cotton cultivated farmers are considered for the analysis. From the detailed observational sample survey method, it is observed among the farmer suicide cases which have been recorded from August, 2015 to October, 2015, majority of the farmers who have committed suicide are belongs to the age group of less than 50 years. The average farmer's age is situated at around 43 years. Further, from the comparison of number acres that farmers have been cultivating the figures clearly reflected that majority of the farmers have the area of less than 5 acres and the average land that they cultivate is 3.34 acres and the table clearly shows that majority of the farmers have been cultivating through leased land farming. Among the 51 cases of farmer suicides in different districts of Telangana state, majority of the cases were found doing farming under leased farming. The average debt of the farmer has also shown as 3.35 lakh. Among the sample study it is observed that majority of the farmers who committed suicide were cultivated Cotton which is a Cash crop and further, the suicide cases were clearly revealed that that more than $80 \%$ of the farmers have observed Pesticides for committed suicide. The major reasons among the respondents clearly revealed that extreme indebtness, bankruptcy, farming related issues and extreme failure of yield growth. From the survey results, the following factors are observed.

a) Majority of the farmers committed suicide are marginal and small farmers who are lacking the financial assistance despite the present loan scheme approved by banks and government.

b) Farmers are lacking the information on surface including water level, potentiality of crop cultivation.

c) With reference to cultivation, farmers are lacking the effective management of water sources. Further, the leasing farmers have been facing the excess debt problem due to increasing interest rates imposed by money lenders and actual land owners.

d) lack of field inspections by the district agricultural research agencies, lack of contribution from the government over market conditions and preservation of output for better prices in peak seasons are creating problems for the farmers.

d) with regard to selling the agricultural produce, majority of the farmers are lacking the information about the marketing facilities arranged at the district market centers, further the lack of information about the market prices according to different quality levels are also resulted the farmers to lead depression.

\section{C) Problems Relatd To Marketing Of Agricultural Produce}

From the observations through field visits, it is being observed that the storage facilities with the individual farmers are normally very primitive types in the form of dugholes and pits. A s a result 10-15 percent of agricultural produce gets spoiled either by unexpected rains (especially for cotton and rice crops), weather conditions or may be eaten by any other living things. There are a number of agents between the producers (farmers) and the consumers (Buyers). They charge a heavy amount as their fees or as commission. As a result, the farmers do not get a fair share in the total product price charged. Because of heavy indebtedness, the farmers are mainly times forced to sell their produces at low prices and sometimes due to lack of proper transport facilities in the nearest market at not so great prices.

\section{D) Digital India As A Tool For Curbing Farmer Suicides}


From the realization of the existing problems that farmers have been facing with special reference to Telangana state, the model is designed and presented below.

Table 1: Linking Digital India to different needs of customers

\begin{tabular}{|c|c|c|c|}
\hline Sl.No. & Stage & Type of Assistance needed & $\begin{array}{l}\text { Type of Digital India support } \\
\text { needed for Networking }\end{array}$ \\
\hline 1 & $\begin{array}{l}\text { Stage-I: } \\
\text { Collection } \\
\text { preliminary } \\
\text { information }\end{array}$ & $\begin{array}{l}\text { Information assistance for } \\
\text { farmers with regard to } \\
\text { identification and } \\
\text { evaluation of farm soil, } \\
\text { information on type of crop } \\
\text { to be cultivated, }\end{array}$ & $\begin{array}{l}\text { Integration of Geoinformatics } \\
\text { and broadband services in } \\
\text { association with Panchayats }\end{array}$ \\
\hline 2 & $\begin{array}{l}\text { Stage II: Seed } \\
\text { planning }\end{array}$ & $\begin{array}{l}\text { Purchase of seeds and } \\
\text { planting }\end{array}$ & $\begin{array}{l}\text { Collaboration with agri } \\
\text { researchers, seed companies } \\
\text { regarding crop variation, crop } \\
\text { growth, ploughing, seeding, } \\
\text { watering and use of fertilizers }\end{array}$ \\
\hline 3 & $\begin{array}{l}\text { Stage III: } \\
\text { Financial } \\
\text { assistance }\end{array}$ & $\begin{array}{l}\text { Information on financial } \\
\text { assistance for cultivation, } \\
\text { renewal and new loans, } \\
\text { interest rate, loan waivers, } \\
\text { subsidies }\end{array}$ & $\begin{array}{l}\text { Integration of banking } \\
\text { network, revenue department } \\
\text { and insurance companies } \\
\text { through a common network }\end{array}$ \\
\hline 4 & $\begin{array}{l}\text { Stage IV: Crop } \\
\text { Management }\end{array}$ & $\begin{array}{l}\text { Information on plant food, } \\
\text { agro chemicals }\end{array}$ & $\begin{array}{l}\text { Integration of pesticide } \\
\text { companies, AGRISAT for timely } \\
\text { information }\end{array}$ \\
\hline 5 & $\begin{array}{l}\text { Stage V: Farm } \\
\text { irrigation }\end{array}$ & 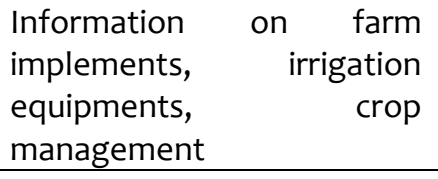 & $\begin{array}{l}\text { Integration of irrigation, water } \\
\text { supply and Geoinformatics, } \\
\text { ICRISAT, agricultural research } \\
\text { institutions }\end{array}$ \\
\hline 6 & $\begin{array}{l}\text { Stage VI: } \\
\text { Storage of farm } \\
\text { produce }\end{array}$ & $\begin{array}{l}\text { Storage of agricultural } \\
\text { produce Grain elevators, } \\
\text { public, ware houses } \\
\text { enabled with refrigeration, } \\
\text { freezer, heated etc. }\end{array}$ & $\begin{array}{l}\text { Online linking of ware house } \\
\text { stock information, availability } \\
\text { and } \mathrm{FCl} \text { support for stocking } \\
\text { and periodical selling }\end{array}$ \\
\hline 7 & $\begin{array}{l}\text { Stage VII: } \\
\text { Transportation }\end{array}$ & $\begin{array}{l}\text { Facilities of transportation } \\
\text { including road, rail and } \\
\text { airlines }\end{array}$ & $\begin{array}{l}\text { Integration of railways, public } \\
\text { and private transport system } \\
\text { for low cost transportation of } \\
\text { agricultural produce }\end{array}$ \\
\hline 8 & $\begin{array}{l}\text { Stage } \\
\text { Selling } \\
\text { marketing }\end{array}$ & $\begin{array}{l}\text { Creation of yield availability, } \\
\text { grade and quality of yield, } \\
\text { Direct selling price from } \\
\text { POP(point of production) }\end{array}$ & $\begin{array}{l}\text { Geoinformatics, Online } \\
\text { National Agricultural trading, } \\
\text { Markfed and Agricultural } \\
\text { committees }\end{array}$ \\
\hline \multirow[t]{2}{*}{9} & $\begin{array}{l}\text { Stage IX: Savings } \\
\text { and investments }\end{array}$ & $\begin{array}{l}\text { Information requirement } \\
\text { for alternative sources for } \\
\text { saving of returns from } \\
\text { agriculture, special schemes } \\
\text { for farmers }\end{array}$ & $\begin{array}{l}\text { Integration of Rythu bandhu, } \\
\text { Coperative agencies, RRBs, } \\
\text { post-offices and insurance } \\
\text { companies. }\end{array}$ \\
\hline & $\begin{array}{l}\text { Stage } \mathrm{X} \text { : Other } \\
\text { supporting } \\
\text { services }\end{array}$ & $\begin{array}{l}\text { Farmer } \\
\text { suggestions oducation, } \\
\text { Water Better } \\
\text { National weather risk } \\
\text { management system }\end{array}$ & $\begin{array}{l}\text { Integration of inromation flow } \\
\text { from Meteorological } \\
\text { Department, Department of } \\
\text { Agriculture and Cooperation } \\
\text { information resource }\end{array}$ \\
\hline
\end{tabular}


Further, the recent discoveries in the information technology will also provide great assistance for the farmers to reduce the problems of cultivating, getting financial assistance and more importantly marketing.

\section{E) Need For Geoinformatics In Digital India As Part Of Co-Ordinating Farmers In Rural Areas}

Rural agricultural market in India is one of the untapped markets as still many companies are competing to enter and excel. Major income of rural consumers is from agriculture. This shows that, rural prosperity is tied with agriculture prosperity. In the event of a crop failure, the income of the rural masses is directly affected. With regard to infrastructure facilities, it is a challenge for marketers who have found innovative ways to market their products. Further, the potentiality of rural market in generating large agricultural produce is the main attraction of rural market. With regard to problems for rural markets, it is observed that lack of communication system is still lacking despite the efforts of many companies and the initiatives of state and central government. The literacy rate in the rural areas especially in farming areas have been resulting in failure in adoption of technology to analyze the market prices of the agricultural commodities, current scenario and the market fluctuations for different agricultural produce. Apart from this, the purchasing power of rural people is directly influenced to seasonal demand. Due to the dependency in the agricultural income, harvest season might see an increase in disposable income and hence more purchasing power is shown in the favorable seasons. Further, the cost is an important factor that determines the purchasing decision in rural areas. A lot of spurious brands or look-alikes are available, providing a low cost option to the rural customer. Many a time the rural customer may not be aware of the difference due to illiteracy. Overall, the rural market in India is quite fascinating and challenging in spite of all the difficulties existing. The potential is enormous even though, these markets have weaknesses they also have tremendous opportunities which should be availed by the marketers.

The utilization of natural resource including the information about the potentiality of crop, changes in weather conditions and fluctuations in the market value of crops are the major constraints, in which there is a dire need to ensure that resources are effectively managed. The advanced technology in the field of natural resources, i.e., Geospatial Information Systems Technologies (GIS Technologies) should be linked to digital India with an aim to provide a platform for providing informative data to the farmers which is expected to play key role in the following areas.

1. Identifying the potential in both rural and urban markets for agricultural produce.

2. Promoting the presence of yield available to the world market.

3. Identifying the penetration region wise and area wise.

4. To identify the network coverage in rural markets as well as identifying new stock points.

5. Providing dealer, marketers and potential surveys

6. Generating location element to the sales and distribution data used by the enterprises.

7. Identifying the key geographical areas with potentiality for agricultural growth in yield

8. Finding the areas with more revenue potential in rural markets.

9. Mapping the physical presence

10. Micro level profiling of consumer markets.

In order to attain support for these needs, the Digital India can be used as an intermediary which can simultaneously link the Geoinformatics with farmers to assist all the updated information about the potentiality of crop for different seasons, forecasting the weather fluctuations, ensuring the identification production of the yield at different areas to the potential distributors and buyers and further to provide the information to the farmers about the significant revenue potential markets for the farmers to directly sell 
the yield to achieve better gain over traditional intermediary influenced sales. Overall, Digital India can transform the gains of Geoinformatics to the farmers fr Water Resource Development especially in drought surrounding farming areas, information about climate change, water shed planning for preserving water, soil resources, energy resources, agricultural markets assistance and live market information to farmers, deciding about Horticulture, plantation, Ground water management and diversified employment opportunities in the area of Animal Husbandry and Diary development.

In order to understand the importance of Geoinformatics in the scenario of current rural markets, field survey is adopted and analyzed the requirements of the rural people from the Geoinformatics. Survey results are presented in the following table.

Table 2: Rural peoples rating towards the requirements

\begin{tabular}{|c|l|c|r|}
\hline S.No. & \multicolumn{1}{|c|}{ Statement } & $\begin{array}{c}\text { Weighted } \\
\text { Score }\end{array}$ & Rank \\
\hline 1 & $\begin{array}{l}\text { Training to adopt to the technology for knowing the } \\
\text { benefits of Geoinformatics }\end{array}$ & 3.5 & 5 \\
\hline 2 & $\begin{array}{l}\text { Increase the demand for village products in the urban } \\
\text { market. }\end{array}$ & 3.6 & 4 \\
\hline 3 & $\begin{array}{l}\text { Promoting the specialty of agricultural produce in the } \\
\text { potential market. }\end{array}$ & 3.8 & 3 \\
\hline 4 & $\begin{array}{l}\text { Promoting the availability of agricultural produce for } \\
\text { buyers. }\end{array}$ & 3.9 & 3 \\
\hline 5 & $\begin{array}{l}\text { To expand distribution networks. } \\
\text { Initiation of rural incubation centers for awareness and } \\
\text { adoption of GIS. }\end{array}$ & 3.4 & 1 \\
\hline 7 & $\begin{array}{l}\text { Identification of potential market for selling the agricultural } \\
\text { produce. }\end{array}$ & 4.2 & 6 \\
\hline 8 & $\begin{array}{l}\text { Understanding the spatial technology for integrating in the } \\
\text { agriculture. }\end{array}$ & 3.5 & 2 \\
\hline 9 & Understanding the market prices for agricultural produce & 4.1 & 3.2 \\
\hline 10 & $\begin{array}{l}\text { Mapping the physical presence of agricultural yield to the } \\
\text { potential purchasers }\end{array}$ & 3 \\
\hline
\end{tabular}

\section{Source: field survey \&Weighted Averages}

10 select requirements are identified through pilot study and these requirements are tested by adopting a rating scale. Based on the rating, the ranks are given by applying weighted averages method. From the results, it is to interpret that, highest rank was achieved to the requirement 'identification of potential market for selling the agricultural produce'. The second highest rating was achieved for 'understanding the market prices for agricultural produce'. Apart from these, respondents have given next highest rating to 'promoting the availability of agricultural produce for buyers' and promoting the specialty of agricultural produce in the potential market. From the results it is to conclude that, rural farmers are expecting high for identifying the potential markets and to understand market prices and promoting these to buyers.

\section{F) Creation Of Online National Agriculture Trading}

The recent decision taken by Government on July 1, 2015 shows the action plan of the government towards benefiting the farmers involved in different forms. The proposal on creation of National Agriculture Trading market to help farmers of India expected to integrate the farmers and the buyers under one plot form where the farmer can update all the information about the yield, quality of the production, availability and quantity ready for sale and the proposed price for commodity. Whereas the buyers can mutually 
negotiate with farmers through online platform, it can help to get benefit by direct purchase from the producers (farmers). This can also reduce the problem of intermediary expenses that buyer need to get for agricultural produce. The online platform can also benefit farmers to directly sell the farm produce right at the place of production to avoid the transportation, brokerage, packing and other taxes that they pay to Market committees and Mandis. The farmers are expected to learn the tips and suggestions from experts through online with regard to various aspects of cultivation. The free access to sell via online trade is likely to boost their incomes and improve availability, moderating price rise.

\section{7) Findings And Suggestions}

Digital India should integrate multiple information resources including banking, revenue, insurance, agricultural research institutes, government schemes, Panchayat divisions under one umbrella to provide synergy of information to the farmers about the debt and interest that they have to repay to the bank, possibilities of availing new loans by creating land saving account, details of land in cultivation and ownership of land from Revenue and Panchayats so that the information is shared between all these three sectors in order to provide better financial assistance from banks. This will also benefit the government to take farmer favoured decisions including waiver of interest and waiver of loans availed from banks. The transformation of information flow for all levels will facilitate the farmers the needed assistance there by help them to take the advantage of resources available to them. Digital India should be effectively utilized for productive, competitive, diversified and sustainable agricultural sector growth.

\section{References}

1. Adrian Athique(2012), "Indian media", Polity Press, Cambridge, UK.

2. Aroop Datta(2015), "NaMo: A Name.A Cult, A Visual Delight", Author House Publishers, Bloomington, New York.

3. Chander Mohan et al.(2012), "Role of GIS in Micro level planning watershed management for Rural development", International journal on Research analysis and evaluation, vol.4, issue 39, December, 2012.

4. Ghosh D K, "Digital India: Rural Empowerment and transoformation", UBS Publishers' Distributors, New Delhi, 2006.

5. Kolagani, N., Ramu, P. \& Varghese, K. (2012). Participatory GIS in Empowering Rural Communities: A Framework for Iterative Development and Evaluation, 6th International Congress on Environmental Modelling and Software, Leipzig, Germany, July 1-5, 2012.

6. Pradip Ninan Thomas(2012), "Digital India”, SAGE Publications, New Delhi.

7. Singh A.K. and Chopra U.K.(2007), "Geoinformatics applications in India-retrospect and prospects experience of National Remote Sensing Agency(NRSA)", New India Publishing Agency, New Delhi.

8. Socio Economic Outlook-2015, Report issued by Department of Agriculture, Government of Telangana, 2015.

9. Data retrieved from http://articles.economictimes.indiatimes.com/2015-0701/news/640045291_online-platform-farmers-online-trade

10. Data retrieved from http://ncrb.gov.in/ADSI2014/chapter-2A\%2ofarmer\%20suicides.pdf

11. Data retrieved from http://www.digitalindia.gov.in/content/management-structure

12. Data retrieved from http://www.digitalindia.gov.in/content/programme-pillars

13. Data retrieved from http://www.thehindu.com/data/does-it-pay-to-be-a-farmer-inindia/article6713980.ece 
Table 2: Statistics on framer suicides in 2015 in Telangana state

\begin{tabular}{|c|c|c|c|c|c|c|c|c|c|}
\hline SI.N & Name of the farmer & Age & Place & $\begin{array}{l}\text { Farming } \\
\text { acres }\end{array}$ & $\begin{array}{l}\text { Type of } \\
\text { farming }\end{array}$ & Debt & Type of crop & Type of suicide & Reasons \\
\hline 1 & G.Narayana & 55 & $\begin{array}{l}\text { Govindaayipalli, Tandur mandal, } \\
\text { Mahabubnagar District }\end{array}$ & 10 & Own & 3 lakh & Cotton & Pesticides & Excess debts and dried farm crop \\
\hline 2 & Sai Reddy & 55 & $\begin{array}{l}\text { Mallayipalli, Panagal Mandal, Mahabubnagar } \\
\text { District }\end{array}$ & 6 & Own & 2 lakh & Ground nut & Pesticides & Dried farm crop \\
\hline 3 & Peddha mannem & 48 & $\begin{array}{l}\text { Mojarla Village, Peddha Mandadi Mandal, } \\
\text { Mahabubnagar District }\end{array}$ & 4 & LF & 4 lakh & Ground nut & Pesticides & $\begin{array}{l}\text { Excess debts, lack of returns and LF } \\
\text { demand }\end{array}$ \\
\hline 4 & Chinnaraja Reddy & 50 & $\begin{array}{l}\text { Bhushanarao pet village, Kathalapur Mandal, } \\
\text { Karimnagar District }\end{array}$ & 3 & Own & 5 lakh & Corn, Turmeric & Pesticides & Excess debts, family burden \\
\hline 5 & P. Laxmi & 45 & Katkur village, Bheemdevarapalli Mandal & 3 & LF & 2 lakh & Cotton & Pesticides & Excess debt, family economic crisis \\
\hline 6 & M Padma & 26 & $\begin{array}{l}\text { Jammikunta Thanda village, Kodakandla } \\
\text { Mandal, Warangal District }\end{array}$ & 4 & LF & 2 & $\begin{array}{l}\text { Cotton, rice, } \\
\text { groundnut }\end{array}$ & Hanging & $\begin{array}{l}\text { Excess debts, lack of rain and dried } \\
\text { crop }\end{array}$ \\
\hline 7 & B Chinna Swamy & 62 & $\begin{array}{l}\text { Rekulathanda village, Kuravi mandal, } \\
\text { Warangal District }\end{array}$ & 3 & Own & 2 lakh & $\begin{array}{l}\text { Rice, mirchi, } \\
\text { cotton }\end{array}$ & Hanging & $\begin{array}{l}\text { Excess debts and lack of rain and } \\
\text { dried crop }\end{array}$ \\
\hline 8 & M Narsimha Reddy & 46 & $\begin{array}{l}\text { Shankarpalli mandal, Mahalingapuram village, } \\
\text { Rangareddy District }\end{array}$ & 6 & LF & 6.5 lakh & Cotton & Hanging & Lack of result for crop and yield \\
\hline 9 & P Pullaiah & 27 & $\begin{array}{l}\text { Chandralagudem village, Paloncha Mandal, } \\
\text { Khammam District }\end{array}$ & 8 & LF & -- & Cotton & Hanging & Crop yield decrease \\
\hline 10 & Balsingh & 45 & $\begin{array}{l}\text { Bommarigudem, Pulkal Mandal, Medak } \\
\text { District }\end{array}$ & 4 & Own & 4 & Rice, cereals & Hanging & Crop yield decrease \\
\hline 11 & Srisailam & 33 & $\begin{array}{l}\text { Ismaelkhan peta, Sangareddy Mandal, } \\
\text { Sangareddy District }\end{array}$ & 5 & LF & 3 lakh & Cotton & Pesticides & Crop yield \\
\hline 12 & K Bhaskar Reddy & 38 & $\begin{array}{l}\text { Jagannadhpur village, Elkathurthi mandal, } \\
\text { Karimnagar District }\end{array}$ & $2 \frac{1 / 2}{2}$ & Own & 2.50 lakh & Cotton & Suicide in well & Crop yield, family and excess debts \\
\hline 13 & B Kanakaiah & 65 & Raikal in Saidapur Mandal, Karimnagar Distric & 2 & $\mathrm{LF}$ & 2 Lakh & Cotton & Hanging & Lack of rain and yield problems \\
\hline 14 & G Ramesh & 35 & $\begin{array}{l}\text { Kistarao Palli, ramadugu mandal, Karimnagar } \\
\text { District }\end{array}$ & 2 & LF & 6 lakh & Cotton & Pesticides & Lack of returns from yield \\
\hline 15 & J Srinu & 30 & $\begin{array}{c}\text { Chirrakuna thanda, Gudur mandal, Warangal } \\
\text { District }\end{array}$ & 2 & Own & 2.50 lakh & Rice, cotton & Pesticides & Lack of returns, family economic crisis \\
\hline 16 & N Arjun Rao & 64 & $\begin{array}{l}\text { Kaniparthi village, Regonda Mandal, Warangal } \\
\text { district }\end{array}$ & 3 & Own & 4 lakh & Cotton, mirchi & Pesticides & Lack of economic growth, lack of rain \\
\hline 17 & M Anjilaiah & 40 & $\begin{array}{c}\text { Rupkhanpet, Parigi mandal, Rangareddy } \\
\text { District }\end{array}$ & 3 & Own & 2 lakh & Cotton & Pesticides & Lack of returns, excess bank debts \\
\hline 18 & G Janardhan & 24 & Kobbayi village, Bela Mandal & 5 & Own & 1 lakh & Cotton, cereals & Pesticides & Lack of yield growth, lack of rains \\
\hline 19 & D Krishna & 36 & $\begin{array}{l}\text { Lingotam village, nampalli mandal, nalgonda } \\
\text { District }\end{array}$ & 5 & LF & 3 lakhk & Cotton & Pesticides & Lack of rains,ces debts, family crisis \\
\hline 20 & A Mangamma & 40 & Kothapocharam village, Garla Mandal & 3 & LF & 6 lakh & $\begin{array}{l}\text { Cotton, mirchi, } \\
\text { rice }\end{array}$ & Suicide in well & Lack of returns, family financial crisis. \\
\hline 21 & B Ellaiah & 40 & Ajilapur, Veldenda mandal, Mahaboob Nagar & 7 & Own & 5 lakh & Cotton & Pesticides & Excess debts \\
\hline
\end{tabular}




\begin{tabular}{|c|c|c|c|c|c|c|c|c|c|}
\hline & & & District & & & & & & \\
\hline 22 & V Nirmalamma & 38 & Ponnakal village, Addakula mandal & 3 & Own & 2 lakh & Cotton & Burnt in kerosene & Excess debts \\
\hline 23 & G Narsimha & 60 & Kadirepahad, Mahboobnagar & & Own & & & $\begin{array}{l}\text { Touched current } \\
\text { wires }\end{array}$ & Excess debts \\
\hline 24 & M Ramesh & 35 & Midjil Mandal, Rachalapalli mandal & 5 & Own & Lakh & Cotton, corn & Pesticides & Excess debts, family economic crisis \\
\hline 25 & Ramulu & 30 & $\begin{array}{l}\text { Ogodu village, Nakirekal mandal, } \\
\text { Nalgonda District }\end{array}$ & & Own & 6 lakh & Cotton & Pesticides & Lack of yield return \\
\hline 26 & S Jangireddy & 55 & $\begin{array}{l}\text { Gonakal village, Dindi gram panchayat, } \\
\text { Nalgonda district }\end{array}$ & 3 & Own + LF & 3 lakh & Cotton & Pesticides & Lack of yield return \\
\hline 27 & H Saritha & 32 & $\begin{array}{l}\text { Borlagudem village, Mahamutharam mandal, } \\
\text { Karimnagar District }\end{array}$ & 2 & $\mathrm{LF}$ & 1 lakh & $\begin{array}{l}\text { Cotton, } \\
\text { Vegetables }\end{array}$ & Pesticides & Crop was destroyed by forest animals \\
\hline 28 & G Srinu & 30 & Elkaurthi Havel village, Gesukondal mandal & $21 / 2$ & LF & 2.4 lakh & Cotton & Pesticides & Drought and lack of yield growth \\
\hline 29 & D Narsimharao & 40 & $\begin{array}{l}\text { Timmampeta, Mangapet mandal,Warangal } \\
\text { district }\end{array}$ & 4 & $\mathrm{LF}$ & 2 lakh & Mirchi & Pesticides & $\begin{array}{l}\text { Family health and economic issues, } \\
\text { drought, lack of yield growth }\end{array}$ \\
\hline 30 & N Ravi & 45 & Gudur villae, kamalapur mandal & 2 & LF & 2 lakh & Cotton & Pesticides & $\begin{array}{c}\text { Borewel failure, Ick of water supply to } \\
\text { crops }\end{array}$ \\
\hline 31 & S Maipal & 30 & Warangal District & 3 & Own & 2 lakh & Corn & Hanging & Lack of water supply for crops \\
\hline 32 & K Bakkanna & 35 & Appareddy village, Mahaboobnagar district & 4 & Own & 8 lakh & Cotton & Pesticides & Economic crisis, lack of yield \\
\hline 33 & H Dubbanna & 42 & Dornad, Dharumandal, Mahboobnagar & 2 & Own & 2 lakh & Cotton & Pesticides & Lack of growth in yield, and rain fall \\
\hline 34 & Saireddy & 55 & Mallaipalli villae, pangal mandal & 5 & Own & 2 lakh debt & Cotton & Pesticides & $\begin{array}{l}\text { Lack of water supply, lack of yield } \\
\text { growth }\end{array}$ \\
\hline 35 & N Kistaiah & 40 & Peerlapalli village, jagadevpur Mandal & 2 & Own & 3 lakh & Cotton & Hanging & Lack of yield growth \\
\hline 36 & V Narsaiah & 63 & $\begin{array}{l}\text { Komalla village, Raghunathpalli mandal, } \\
\text { Warangal district }\end{array}$ & 2 & Own & 4 lakh & Cotton & Pesticide & Rain deficit \\
\hline 37 & G Malla Reddy & 42 & Ananthasagar village, Medak district & 2 & Own & 5lakh & Cotton & Pesticide & Rain and drought \\
\hline 38 & T Mangya & 36 & $\begin{array}{l}\text { Munagala village, Madhira mandal, Khammam } \\
\text { District }\end{array}$ & 3 & Own & 1.50 lakh & Cotton & Pesticide & Drought, lack of water supply to crop \\
\hline 39 & A Narayana & 45 & $\begin{array}{l}\text { Chinnabonala village, sirisilla mandal, } \\
\text { karimnagar District }\end{array}$ & $1 \frac{11 / 2}{2}$ & Own & 4 lakh & Cotton & Pesticide & Lack of water supply to crop \\
\hline 40 & M Nagireddy & 30 & $\begin{array}{l}\text { Doranda, Timmapur mandal, Karimnagar } \\
\text { District }\end{array}$ & $3 \frac{1}{2}$ & Own & 3 lakh & $\begin{array}{l}\text { Rice, corn, } \\
\text { vegetables }\end{array}$ & Pesticides & Lack of rain fall, water supply \\
\hline 41 & M Ramulu & 58 & $\begin{array}{l}\text { Kammarivada, Korutta mandal, Karimnagar } \\
\text { District }\end{array}$ & 1 & LF & 5 lakh & Cotton & Pesticides & $\begin{array}{l}\text { Family health problems, lack of } \\
\text { economic power }\end{array}$ \\
\hline 42 & M Jalapathi & 40 & Sriramulapalli Village, Ramaduga Mandal & 1 & LF & Lakhk & Cotton & Pesticides & Lack of yield growth \\
\hline 43 & N Sudhakar & 34 & $\begin{array}{l}\text { Bammera Village, Palakurthi mandal Warangal } \\
\text { District }\end{array}$ & 2 & LF & $60000 \mathrm{rs}$. & Cotton and rice & Heart attack & $\begin{array}{l}\text { Lack of water supply, crop growth } \\
\text { decline }\end{array}$ \\
\hline 44 & P Venkat Rao & 60 & $\begin{array}{l}\text { Errabelli Village, Parakal Mandal,Warangal } \\
\text { District }\end{array}$ & 1 & LF & $70000 \mathrm{rs}$. & Cotton & Heart attack & Lack of yield growth \\
\hline 45 & K Saraiah & 45 & Parakal, Warangal district & 2 & LF & 2 lakh & Rice, cotton & Heart attack & Lack of yield growth \\
\hline 46 & E Aadaiah & 45 & Gesukonda, Warangal District & 3 & Own & 1.3 lakh & Cotton & Pesticides & Lack of growth in yield \\
\hline 47 & E raju & 40 & Pothram village, Warangal District & 3.3 & LF & 7 lakh & Cotton, rice & Pesticides & $\begin{array}{l}\text { Lack of water supply, lack of growth } \\
\text { in yield }\end{array}$ \\
\hline 48 & G Ramulu & 45 & Munipally village, Medak District & 8 & LF & 4 lakh & Cotton & Hanging & Lack of yield growth, excess debts \\
\hline 49 & S Kavith & 30 & Dakur Village, Andol mandal, Khammam & 4 & Own & 4 lakh & Cotton & Pesticides & Lack of yield growth, debts \\
\hline
\end{tabular}




\begin{tabular}{|c|c|c|c|c|c|c|c|c|c|}
\hline & & & District & & & & & & \\
\hline 50 & Ganga Rajam & 45 & $\begin{array}{l}\text { Thatlavayi village, raikal mandal, Karimangar } \\
\text { district }\end{array}$ & 3 & Own & 7 lakh & Cotton & Pesticides & Excess debts \\
\hline 51 & Rajamallaiah & 48 & Ayilapur, Korutla mandal, Karimangar & $1 \frac{1 / 2}{2}$ & Own & 3 lakh & Cotton, corn & Hanging & Excess debts, lack of yield growth \\
\hline
\end{tabular}

Note: source: reports published in Sakshi, Andhra Jyothis News papers from September-November, 2015

OW- Own land, LF- Leased farming 
Annexure 2: Cotton cultivation in Telangana state from 2006-07 to 2015-16

\begin{tabular}{|c|c|c|}
\hline Sl. No. & Period & Cultivated land in Hectares \\
\hline 1 & $2006-07$ & 153639 \\
\hline 2 & $2007-08$ & 160086 \\
\hline 3 & $2008-09$ & 167719 \\
\hline 4 & $2009-10$ & 173653 \\
\hline 5 & $2010-11$ & 223394 \\
\hline 6 & $2011-12$ & 268721 \\
\hline 7 & $2012-13$ & 277641 \\
\hline 8 & $2013-14$ & 239789 \\
\hline 9 & $2014-15$ & 228057 \\
\hline 10 & $2015-16$ & 248535 \\
\hline
\end{tabular}

Source: Department of Agriculture, Government of Telangana

Annexure 4: government approved price for Cotton

\begin{tabular}{|c|c|c|}
\hline Sl. No. & Percent of Wetness & Approved Price(Rs.) per quintal \\
\hline 1 & Less than 6\% & 4182 \\
\hline 2 & $8 \%$ & 4100 \\
\hline 3 & $9 \%$ & 4059 \\
\hline 4 & $10 \%$ & 4018 \\
\hline 5 & $11 \%$ & 3977 \\
\hline 6 & 12 & 3936 \\
\hline
\end{tabular}

Supporting images:

1. Applications of Geoinformation systems

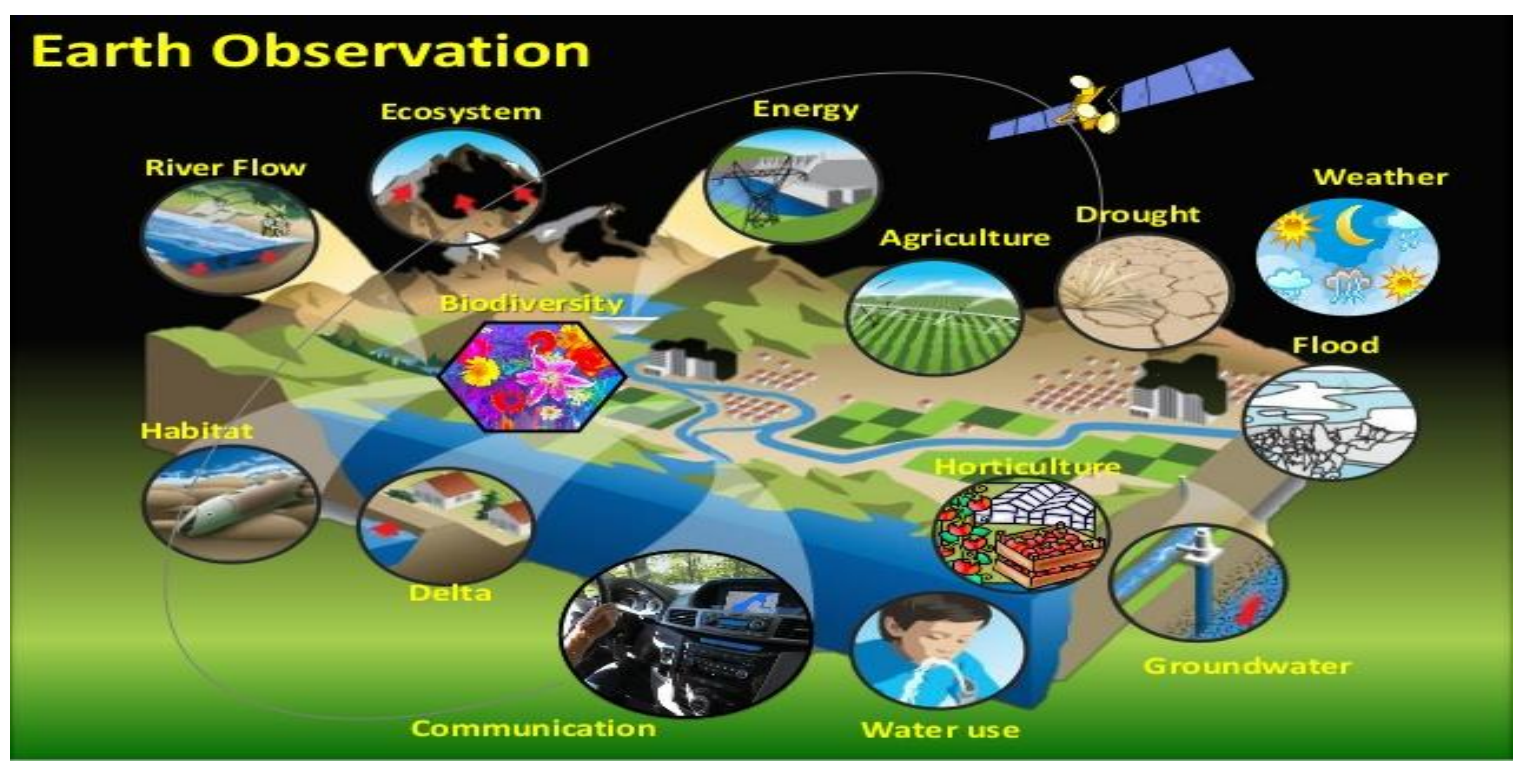

Source: CGARD, National Institute of Rural Development \& Panchayat Raj, Hyderabad 
2. Functioning of Geoinformation system for rural markets

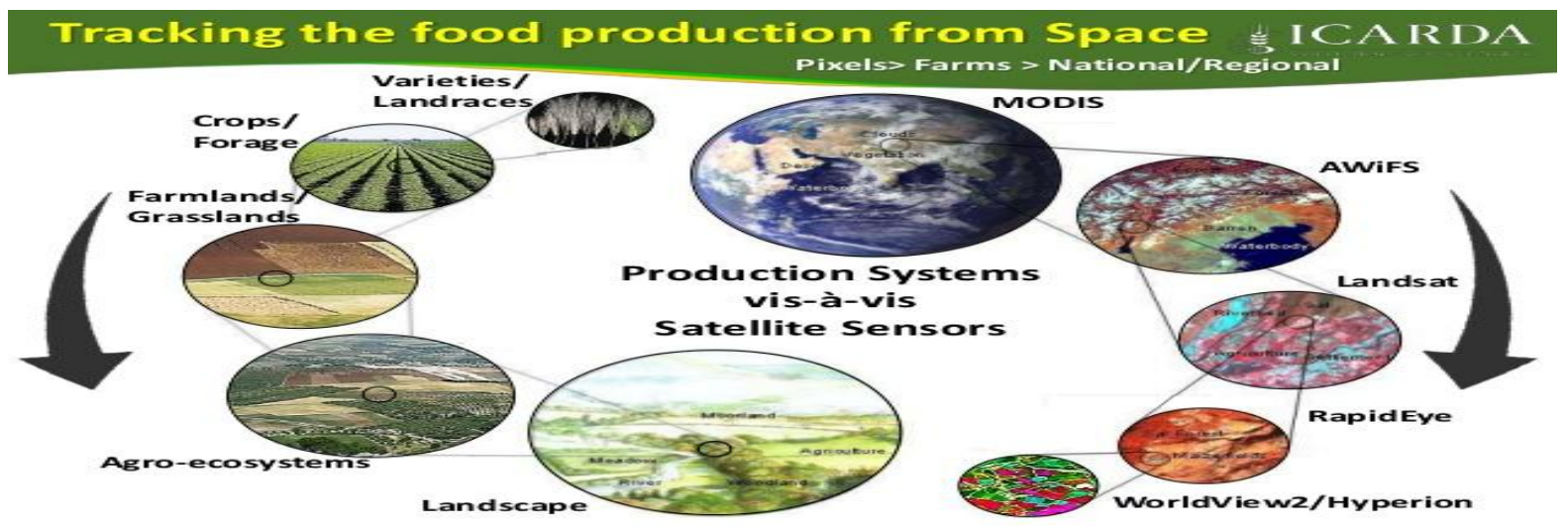

Source: CGARD, National Institute of Rural Development \& Panchayat Raj, Hyderabad

3. Farmer suicide statistics

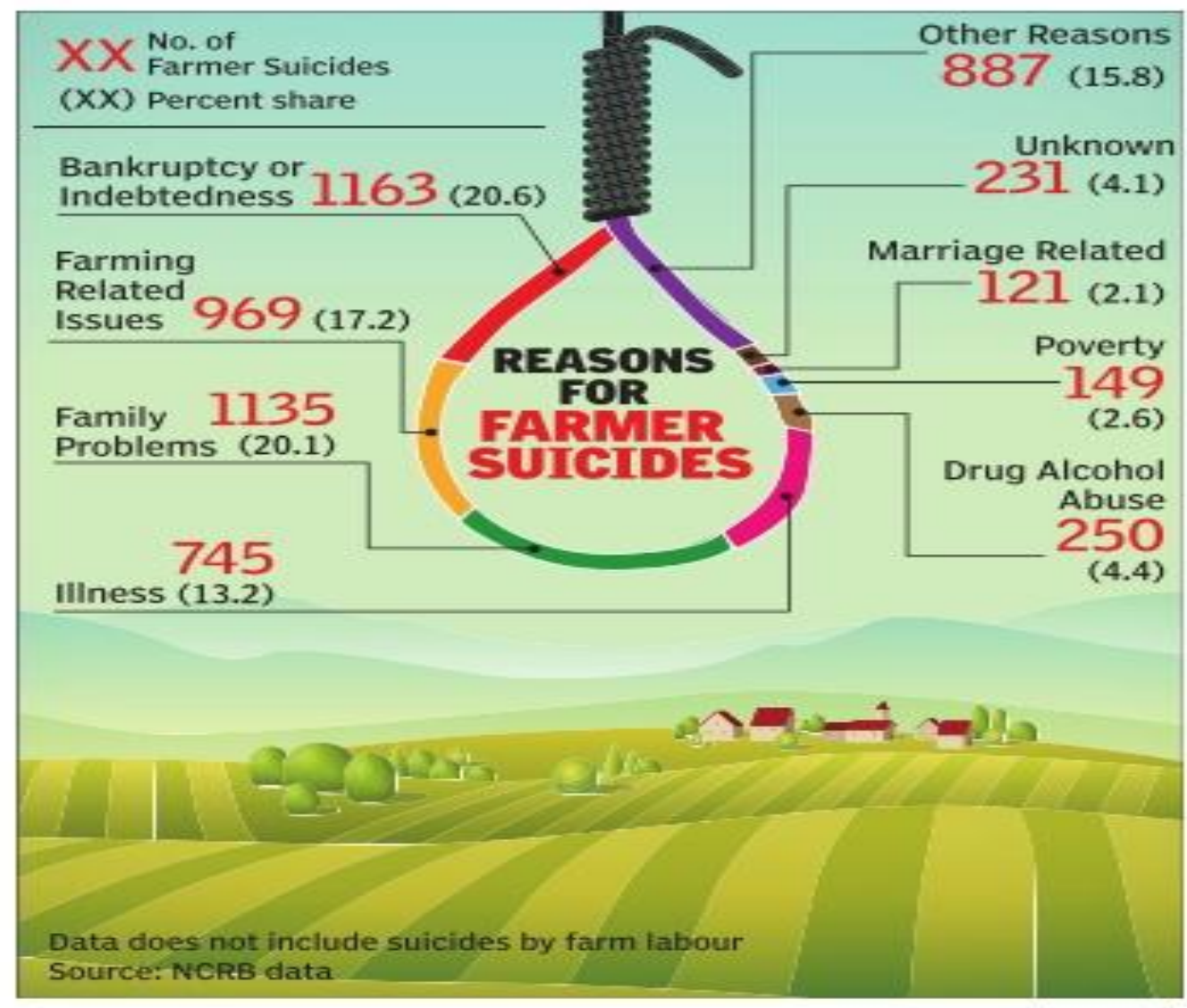

Source: NCRB data 